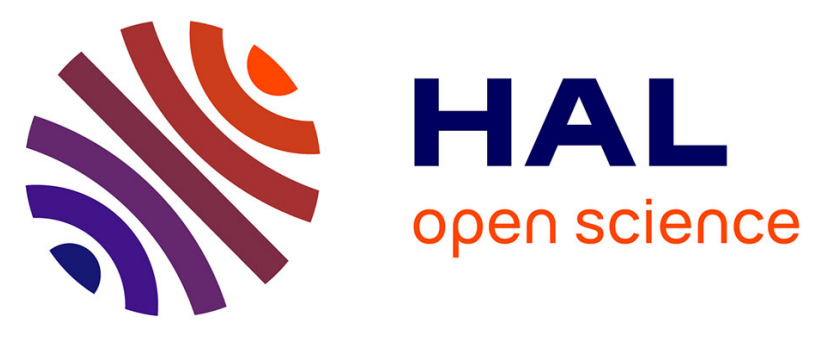

\title{
Perceived ecosystem services (ES) and ecosystem disservices (EDS) from trees: insights from three case studies in Brazil and France
}

\author{
Fernanda Zimmermann Teixeira, Laura Bachi, Julien Blanco, Ilaine \\ Zimmermann, Iara Welle, Sonia M. Carvalho Ribeiro
}

\section{To cite this version:}

Fernanda Zimmermann Teixeira, Laura Bachi, Julien Blanco, Ilaine Zimmermann, Iara Welle, et al.. Perceived ecosystem services (ES) and ecosystem disservices (EDS) from trees: insights from three case studies in Brazil and France. Landscape Ecology, 2019, 34 (7), pp.1583-1600. 10.1007/s10980019-00778-y . hal-02268412

\section{HAL Id: hal-02268412 \\ https://hal.science/hal-02268412}

Submitted on 15 Apr 2021

HAL is a multi-disciplinary open access archive for the deposit and dissemination of scientific research documents, whether they are published or not. The documents may come from teaching and research institutions in France or abroad, or from public or private research centers.
L'archive ouverte pluridisciplinaire HAL, est destinée au dépôt et à la diffusion de documents scientifiques de niveau recherche, publiés ou non, émanant des établissements d'enseignement et de recherche français ou étrangers, des laboratoires publics ou privés. 
This document is the author version of the following article:

Teixeira FZ, Bachi L, Blanco J, Zimmermann I, Welle I, Carvalho-Ribeiro SM. 2019. Perceived ecosystem services (ES) and ecosystem disservices (EDS) from trees: insights from three case studies in Brazil and France.

Landscape Ecology. https://doi.org/10.1007/s10980-019-00778-y

Perceived Ecosystem Services (ES) and Ecosystem Disservices (EDS) from Trees: insights from three case studies in Brazil and France

Fernanda Zimmermann Teixeira ${ }^{1,4 *}$, , Laura Bachi ${ }^{1,5 \psi}$, Julien Blanco ${ }^{2, a} \psi$, Ilaine Zimmermann ${ }^{3}$, Iara Welle ${ }^{3}$, Sónia M. Carvalho-Ribeiro ${ }^{1,6}$

${ }^{1}$ Programa de Pós-Graduação em Análise e Modelagem de Sistemas Ambientais, Universidade Federal Minas Gerais, Instituto Geociências, Departamento de Cartografia, Av. Antônio Carlos, 6.627, CEP: 31270-901, Belo Horizonte, MG, Brazil.

${ }^{2}$ Dynafor, Université de Toulouse, INRA, INPT, INPT - EI PURPAN, Castanet-Tolosan, France.

${ }^{3}$ Foco Estudos Socioambientais, Av. Pereira Passos, 162, CEP 91900-240, Porto Alegre, Brazil.

${ }^{4}$ ORCID: 0000-0002-5634-5142

${ }^{5}$ ORCID: 0000-0002-6009-1587

${ }^{6}$ ORCID: 0000-0002-3045-8632

a Present address: UMR CNRS 6554 LETG-Angers, UFR sciences, Université d'Angers, France

* Corresponding author: fernandazteixeira@ gmail.com, +55-51-99883-64-90

* Shared authorship 


\begin{abstract}
Context - The Landscape approach and the Ecosystem Services (ES) framework have been widely used to investigate human-nature relationships and orient landscape planning and management. However, ecosystem disservices (EDS) and their influence on how people interact with ecosystems have received less attention.

Objective - We aimed at assessing people's preferences and perceptions of forest ES and EDS in three contrasted case studies. In the meantime, it aims at discussing the potential of considering both ES and EDS in landscape preference and sociocultural valuation studies.

Methods - Interviews with stakeholders were conducted in an agroforestry landscape (France), in the Atlantic Forest and in the Pampa grasslands (Brazil). Identified ES and EDS were classified into a common typology and analyzed through discourse analysis and quantitative methods to assess the variability in ES/EDS perceptions among respondents and among forest types.

Results - Respondents cited 19 ES classes and 11 EDS classes, with strong variability among case studies. Contrasted perceptions and preferences among respondents were revealed. In the agroforestry landscape, EDS were particularly emphasized by people and contributed to the variability in people's perceptions. In the Atlantic forest landscape, forested areas tended to contrast based on cultural ecosystem services. In the Pampa case study, EDS were particularly salient in people's preferences concerning exotic forest plantations.

Conclusions - This study suggests that different types of forested areas produce specific ES/EDS, suggesting their complementarity at the landscape scale. The combination of ES and EDS therefore offers a promising research avenue for more consistent ES sociocultural valuations and for improving management recommendations.
\end{abstract}

\title{
Keywords:
}

Sociocultural valuation; Preferences; Perceptions; Place-based research; Forest ecosystems; Landscape values. 


\section{Introduction}

Despite the widespread call for science to engage with society in order to reverse the ongoing ecological crisis, comprehensive approaches are still lacking to address this multifaceted challenge (Agrawal and Ostrom 2006). Landscape approaches (Arts, Buizer et al. 2017) and the Ecosystem Services (ES) framework have been widely used in both research and policy making, and showed to be promising to improve the science-policy interface and tackle environmental challenges (Wood, Jones et al. 2018). Considerable resources have effectively been devoted to assess ES and landscapes at different scales of governance for better targeting land use policy and steering away from unfavorable trends of land use change (Willemen, Hein et al. 2010, Willemen, Veldkamp et al. 2012). On the one hand, the expansion of areas of agriculture and silviculture at the expense of native forest areas have been highlighted as one of the main causes of biodiversity erosion and ES depletion in a vast number of biomes worldwide (Green et al. 2005; Lapola et al. 2014). On the other hand, the intensification of land use in the most productive agricultural areas has led to farmland abandonment and forest regeneration in less productive areas (van der Zanden et al. 2018). As trees and forests provide multiple ES to human societies, this recovering may contribute to restoring the material and non-material benefits provided by landscapes (Torralba et al. 2016). Yet, for some local stakeholders, forest encroachment can be perceived as a negative outcome associated with a decline in agricultural activities and rural exodus (van der Zanden et al. 2018), and with landscape closure. Similarly, the increase of forest areas for silvicultural exploitation has drawn particular attention. Therefore, there is a contextdependent mismatch between ecological processes and the associated ES supply, and the way people perceive and use the processes, i.e. ES demand (e.g. Baró et al. 2015). As a consequence, it is today critical to better assess and map ES demand in order to better inform on stakeholders' preferences, perceptions and views toward environmental management (Wolff et al. 2015).

Studies following "the landscape approach" have actively focused on people's perceptions and preferences for forested landscapes (Carvalho-Ribeiro and Lovett 2011; Carvalho-Ribeiro et al. 2016). Sheppard and Meitner (2005, p.7) define preferences for forests as "the degree to which a person or group prefers a situation or feature over other situations or features" and they also argue that these may vary according to whether scenic beauty (attractiveness) or management strategy (for either food/fiber production or biodiversity conservation) is under consideration (functional relationship) (Carvalho-Ribeiro and Lovett 2011). Perceptions, on the other hand, are defined by Antrop (2000, p.19) as "complex learning processes, analyses the observation immediately and interactively and links the results with our knowledge and past experience". If perceptions are known to be more intangible and difficult to grasp than preferences (Carvalho-Ribeiro et al. 2016), sociocultural valuation of ES aims at assessing the importance people assign to ES (Scholte et al. 2015) and allows an assessment of both ES and EDS cognitive values, at the crossroad between preferences and perceptions.

ES and landscape preferences studies have shown that people have a multidimensional relationship with trees and forests. People value forests for their provisioning ES such as timber or firewood, for their regulating ES such as flood regulation, and for their cultural ES such as recreation. Yet, because people do not value equally these different aspects, they have contrasted preferences. For example, one picking up berries will prefer small shrub forests while a lumberjack will value forests managed for timber; one looking for scenic beauty may not be aware of the issues involved into ecological management (Carvalho-Ribeiro and Lovett 2011). Research on landscape preferences and perceptions generally distinguishes the direct managers of landscapes (e.g. farmers, foresters, etc.) from people with no direct role on landscape management (Ovaskainen and Kniivila 2005; Carvalho-Ribeiro and 
Lovett 2011; Carvalho-Ribeiro et al. 2013). These two broad groups have contrasted landscape preferences (Martín-López et al. 2012; Iniesta-Arandia et al. 2014; Garrido et al. 2017), which has important implications for landscape planning and management (Ramos et al. 2016; Almeida et al. 2016).

Besides differences between people in ES preferences, research has highlighted that people sometimes perceive ecosystem disservices (EDS) related to trees and forests (Agbenyega et al. 2009; Blanco et al. 2018). EDS are defined as the ecosystem generated functions, processes and attributes that result in perceived or actual negative impacts on human wellbeing (Shackleton et al. 2016). They are generated by three different processes. First, an ecosystem function or attribute may impact human wellbeing directly. Mangroves, for example, might be associated to source of malaria outbreaks (Friess 2016). Second, an EDS may cause a diminished flow of ES. For example, crop raiding by mammals living in forests is an EDS resulting in crop production depletion (Ango et al. 2016). Third, an EDS may cause the loss of a supporting or regulating ES (Shackleton et al. 2016), such as forest wildfires (Ninan and Kontoleon 2016). Thus, forests provide simultaneously ES and EDS. However, most research efforts to date have focused on ES (Sell et al. 2007; Farley 2012; Lambin et al. 2014) and, despite the emerging attention on EDS, perceived negative impacts of ecosystems on human wellbeing remains overlooked.

In this paper, we report results from three case studies where ES/EDS preferences regarding trees and forests were assessed using a common ES/EDS framework. Using both "the landscape" and the ES approaches, we explored how different stakeholders (farmers, tourists, local residents) perceive ES and EDS from trees and forests, as well as how different types of forests are perceived. The three case studies were selected to show contrasted contexts and challenges for landscape management and, thus, to illustrate the complementary of the ES and EDS concepts for assessing the sociocultural value of forested areas in different socioecological contexts. Case studies were analyzed separately, as they use different approaches and methods (Simensen, Halvorsen et al. 2018). All three case studies were further assessed using a common ES/EDS framework to highlight how landscape preferences may help to understand land use change and eventually reverse unsustainable land use trends. Finally, we discuss the strengths and limitations of the ES/EDS concepts to unravel landscape preferences and perceptions, and we identify key research perspectives.

\section{Methods}

Study areas

\section{Agroforestry case study}

The first case study is a temperate agricultural landscape, located in southwestern France (43⒈ $13^{\prime} 02.63^{\prime \prime}$; $\left.0^{\circ} 52^{\prime} 53.76^{\prime \prime}\right)$ in the Canton of Aurignac, about $80 \mathrm{~km}$ south-west of the city of Toulouse, and is part of the LongTerm Socio-Ecological Research (LTSER) platform "Vallées et Coteaux de Gascogne" (Fig 1). This hilly agricultural landscape is part of the Pyrenees mountains piedmont and is dominated by mixed farming combining crop cultivation (maize and wheat are the dominant crops), and livestock raising (mostly cows for meat and milk production) on meadows and grasslands. Trees are omnipresent in this landscape, especially in the form of hedgerows, small forest patches and scattered trees (Fig 1). Their management is mostly undertaken by farmers and is very dependent on the timing and type of agricultural activities. Yet, while trees and forests were used as a source of multiple forest resources by farmers, a decline of these traditional uses has been occurring as a result of the modernization of rural livelihoods, which has impacted management practices (Sourdril et al. 2012). Furthermore, their dynamics over the last decades - characterized by an overall decline of hedgerows but a stability 
of small forest patches - were shown to be ultimately linked to changes in the agricultural systems (i.e. the industrialization of agriculture) and in the rural society (i.e. rural exodus and the decline in the number of active farmers, Blanco et al. 2018). Thus, the main challenge in this case study was to understand how local farmers perceive and manage trees and forests so as to eventually reconcile forest conservation with agriculture.

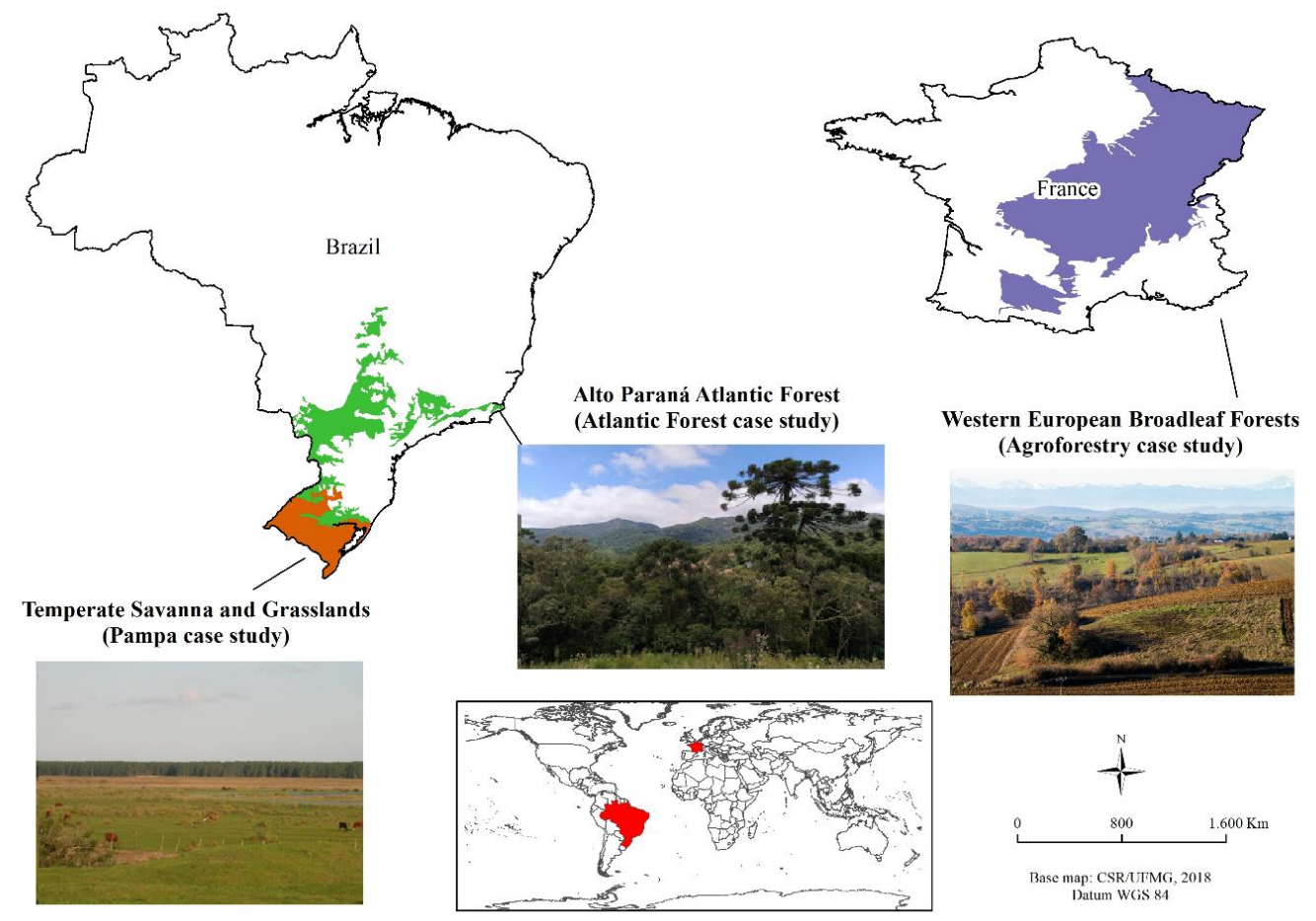

Fig 1 Map of the study areas for the three case studies showing the ecoregions for the three areas

\section{$\underline{\text { Atlantic case study }}$}

The second case study was conducted in the Alto Paraná Atlantic Forest ecoregion (Fig 1) which is part of the Atlantic Forest biome, one of the most threatened Brazilian biomes and a biodiversity hotspot (Bellard et al. 2014). In southeastern Brazil, the Atlantic Forest in the Serra da Mantiqueira, a mountain range and ecological reserve of the Atlantic Forest, has predominant High Mountainous Forest, Dense Ombrophilous Forest and Araucaria Forest (Araucaria angustifolia) (Siqueira 2012). These forested areas located in the high altitudes of the Serra da Mantiqueira constitute a touristic hotspot of the Monte Verde district, especially in winter. Thus, the main challenge in this case study was to understand how different stakeholders (i.e. tourists, local residents, and tourism entrepreneurs) perceive trees and forests and their associated ES and EDS.

\section{Pampa case study}

The third case study was developed in the Pampa biome in Southern Brazil, one of the most species-rich grasslands in the world (Overbeck et al. 2007), in the ecoregion of Temperate Savannas and Grasslands (Fig 1) (Olson and Dinerstein 2002). The expansion of agriculture, particularly soybean and rice plantations, is the main threat to the conservation of grasslands in this region, and it causes substantial land use changes. Furthermore, afforestation mainly with pines and eucalyptus tree plantation for commercial purposes is currently causing major changes in this region covering around 2 million ha (Overbeck et al. 2007), with further conversion of large areas of grassland 
into planted commercial forests over the next few years. Thus, the main challenge in this case study was to understand how local residents in rural areas perceive the ongoing landscape changes and, in particular, the expansion of eucalyptus plantations, and how they relate these changes to ES and/or EDS.

\section{Data collection}

\section{Agroforestry case study}

In-depth interviews were conducted to assess farmers' perceptions of ES and EDS associated with trees and forests. A total of 26 farmers were investigated in a preliminary phase in order to design the interview protocol. This faceto-face interview protocol was fully applied to 18 farmers between January and March 2017. For each interview, farmers were firstly asked to describe their management practices regarding trees and forests in their farms, and to explain their motivations. In particular, they were asked about (i) what types of forested areas they had on their farms, (ii) the ecosystem services (i.e. the advantages and benefits) they got from these forested areas, and (iii) the ecosystem disservices (i.e. the drawbacks and constraints) they suffered from them. Secondly, farmers were asked to provide a synthesis of the most important ES and EDS to them, and to associate these ES and EDS to abovementioned forested areas (for further details see Supplementary Material S1 and Blanco et al. 2018). It resulted, for each farmer, in a mental model linking, in particular, forested areas with their ES/EDS as perceived by the informant.

\section{Atlantic Forest case study}

In order to access landscape users' preferences in the Monte Verde district, 175 structured interviews using a photo-questionnaire were conducted with residents (75) and tourists (100) between November 2016 and July 2017 (Carvalho-Ribeiro et al. 2013; Schirpke et al. 2016). The questionnaire was divided into two blocks of questions (for further details see Supplementary Material S2). In the first one, interviewees were prompt to relate land cover patterns to cultural ES in the touristic landscape, focusing on the places they visited (for tourists) or on the places they use in their daily life (for local stakeholders). They were asked to answer to the questions: "Is there any place in Monte Verde that you do not like? Why?" The second block of questions aimed at having a deeper understanding of people's preferences by asking questions about their preferences related to forest land covers and a sequence of photographs of the spatial patterns of land cover from the Serra da Mantiqueira in the Alto Paraná Atlantic Forest ecoregion.

\section{Pampa case study}

In this case study, local residents living near eucalyptus plantations were interviewed using semi-structured questionnaires to investigate their preferences about the presence of eucalyptus plantations. These surveys were part of the environmental licensing process of eucalyptus plantations at the state level, including monitoring the socioeconomic impacts of silviculture. We investigated the direct and indirect impacts of afforestation in the economic dynamic of the municipalities and the preferences of the communities living around areas with silviculture in relation to landscape changes, environmental impacts, and actions of the company that owns the silviculture areas. Between 2010 and 2017, semi-structured surveys were applied to 1,444 people that lived near eucalyptus afforestation areas in 29 municipalities in Rio Grande do Sul state. Municipalities with large stands of eucalyptus plantations were selected for the surveys and interviews were carried out close to when eucalyptus 
stands were managed (planting and cutting) in each municipality. The questionnaires had about 50 questions focusing on the perceived environmental and socioeconomic alterations due to the presence of eucalyptus plantations. Each survey lasted between 30 minutes and $1 \mathrm{~h} 15 \mathrm{~min}$. This manuscript explores the results obtained from these surveys in relation to one of those 50 questions: "Were there landscape alterations with the presence of eucalyptus plantations? If yes, how?" (for further details see Supplementary Material S3).

\section{Data analysis}

\section{Classification of perceived ES and EDS}

A common ES/EDS typology was used to classify the answers obtained in the three case studies that used different methods of landscape characterization (Simensen, Halvorsen et al. 2018). For ES, we used the 5.1 version of the Common International Classification of Ecosystem Services (CICES, Haines-Young and Potschin 2018), that accounts for provisioning, regulating, and cultural ES. For EDS, there is no such an internationally accepted classification and existing proposals in the literature remain generally context-specific (e.g. for urban ecosystems, Lyytimäki 2014). We therefore created our own EDS typology on the basis of (i) the classification proposed by Shackleton et al. (2016) that distinguishes economical, health-related and cultural EDS, and (ii) the answers provided by informants (Table 1). As a result, and consistently with the CICES, we obtained a hierarchical classification where each ES/EDS type (e.g. provision ES) contains several ES/EDS classes (e.g. plants used for nutrition), and where each ES/EDS class contains one to several ES/EDS (e.g. wild fruits, mushrooms, etc.).

\section{$\underline{\text { Agroforestry case study }}$}

All interviews were recorded and transcribed to allow discourse analysis with NVivo 11 (QSR International Pty Ltd., 1999-2017). From interviews and mental models, we identified nine different types of forested areas that were relevant to farmers. For each forested area, we calculated the number of ES/EDS cited by farmers. We assumed that important ES/EDS to farmers would be those that are frequently cited, and we calculated the number of occurrences for each ES/EDS as a quantitative indicator of its importance to farmers. For example, firewood was cited by 6 farmers as an ES associated with hedgerows; the number of occurrences for the ES 'firewood' for hedgerows is therefore 6 .

\section{ES/EDS in Brazil: Atlantic Forest and Pampa case studies}

In order to identify subgroups of landscape users in the Atlantic Forest and in the Pampa case studies, we performed a Multiple Correspondence Analysis (MCA) for each one of these two Brazilian ecoregions. We used categorical data such as age class and educational level to identify subgroups of residents and tourists in the Atlantic Forest and Pampa case studies based on their profiles. The subgroups were numbered in order to assist data interpretation. Subsequently, we performed a Correspondence Analysis (CA) to associate the different subgroups' profiles from the Atlantic Forest and the Pampa case studies with ES/EDS and forest types mentioned by them. In the output, the regions of the two-dimensional map from the $\mathrm{CA}$ were named based on the preferences of the subgroups within each region. MCA and CA analyses were done using the packages factoextra and FactoMineR in R software (R Core Team 2017; Nenadic and Greenacre 2007).

For the Atlantic Forest case study, a content analysis on the open questions of the photo-questionnaire was conducted. We started by reading the answers from the photo-questionnaire to classify the EDS and identifying 
the forest types associated to ES/EDS classes for the different landscape user groups. Major forest types mentioned were: Araucaria forest (located at high altitudes in the Atlantic Forest biome), Atlantic forest with species such as samambaia, manacá-da-serra tree, and others. Other forest types mentioned were eucalyptus and pine tree plantations associated to silviculture. Then, the answers related with the preference for ES/EDS classes and forest types by the landscape user groups (e.g. local residents vs tourists) received a binary code (0 for the ES/EDS and forest types that were not preferred, and 1 for the ES/EDS and forest types that were preferred). The frequency of the answers for each user group (form the MCA) was used to create a contingency table for the Correspondence Analysis (CA) of the Atlantic Forest case study. The answers related to the preferences for ES/EDS from the Pampa case study also received binary codes and the sum for each subgroup was used to create a contingency table for Correspondence Analysis (CA).

\section{Results}

Overview of the ES/EDS cited by people in the three case studies

A total of 19 classes of ES (including 5 provisioning, 8 regulating and 6 cultural services) and 11 classes of EDS (including 5 economic, 2 health and 4 cultural disservices) associated with trees and forests were identified in the three case studies (Table 1). In addition, people perceived economic benefits associated with forest conservation, in particular through tourism activities and employment opportunities. The number and nature of ES and EDS varied between the three case studies suggesting an influence of the local context on people's perceptions. In the Agroforestry case study, farmers cited 18 ES and 8 EDS classes, which illustrates the importance of forested areas in their livelihood as well as the competition between trees and agriculture. While regulating ES show synergies between agriculture and trees (e.g. trees regulate erosion), economic EDS also illustrate the perceptions of antagonisms (e.g. trees compete with crops). Beyond material contributions, trees were also important to several non-material aspects (e.g. cultural ES/EDS) which illustrates the cultural significance of forested areas in this region. In the Atlantic Forest case study, cultural ES were the most cited with 5 classes of cultural ES and only one class of provisioning ES and one class of regulating ES (Table 1). This result indicates the non-material relationship between forests and informants, consistently with the aesthetic and recreational dimension of this landscape. EDS were hardly ever mentioned in the Atlantic Forest case study, (the only EDS cited was that tree roots and leaves damage local infrastructure). Finally, in the Pampa case study, economic and cultural EDS were particularly salient in local residents' interviews (5 classes of EDS were cited, Table 1). This suggests that eucalyptus planted forests are poorly appreciated by people that perceive them as a source of material and nonmaterial EDS (Fig 2a). Consistently with local residents' negative attitude towards planted forests, no provisioning ES was cited, which suggests a non-material negative perception of eucalyptus planted forests. Overall, in distinguishing material (i.e. provisioning and regulating ES, economic and health EDS) and non-material (i.e. cultural) ES/EDS (Fig 2b), forested areas were mostly perceived as a source of (i) material ES/EDS in the Agroforestry case study, (ii) non-material ES in the Atlantic forest case study, and (iii) EDS in the Pampa case study. 
Table 1 Number of informants citing each class of service/disservice in the different case studies

\begin{tabular}{|c|c|c|c|c|}
\hline Type & $\begin{array}{c}\text { Classes of ES and EDS (CICES 5.1 Code, if } \\
\text { available) }\end{array}$ & $\begin{array}{l}\text { Agroforestry } \\
\text { case study }\end{array}$ & $\begin{array}{c}\text { Atlantic } \\
\text { Forest case } \\
\text { study }\end{array}$ & $\begin{array}{l}\text { Pampa case } \\
\text { study }\end{array}$ \\
\hline \multirow{5}{*}{ 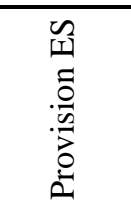 } & Wild plants used as a source of energy (1.1.5.3) & 16 & - & - \\
\hline & Wild plants used for nutrition (1.1.5.1) & 15 & - & - \\
\hline & Fiber and other materials from wild plants (1.1.5.2) & 5 & 86 & - \\
\hline & Wild animals used for nutrition (1.1.6.1) & 4 & - & - \\
\hline & Biomass for agricultural use (1.3.1.1) & 1 & - & - \\
\hline \multirow{8}{*}{ 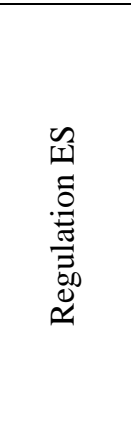 } & Filtration by plants (2.1.1.2) & 1 & - & - \\
\hline & Visual screening (2.1.2.3) & 1 & - & - \\
\hline & Control of erosion rates (2.2.1.1) & 12 & - & - \\
\hline & Water flow regulation $(2.2 .1 .3)$ & 2 & - & - \\
\hline & Wind protection (2.2.1.4) & 11 & - & - \\
\hline & $\begin{array}{l}\text { Maintaining nursery populations and habitats } \\
(2.2 .2 .3)\end{array}$ & 8 & - & - \\
\hline & $\begin{array}{l}\text { Decomposition and fixing process and their effect } \\
\text { on soil quality }(2.2 .4 .1)\end{array}$ & 1 & - & - \\
\hline & $\begin{array}{l}\text { Regulation of air temperature and humidity } \\
(2.2 .6 .2)\end{array}$ & 11 & 52 & 9 \\
\hline \multirow{6}{*}{ 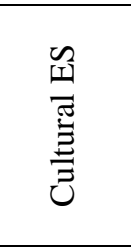 } & Health, recuperation or enjoyment (3.1.1.1) & - & 139 & - \\
\hline & Passive or observational interactions (3.1.1.2) & 1 & 27 & - \\
\hline & Existence value (3.2.2.1) & 7 & 132 & 13 \\
\hline & Option or bequest value $(3.2 .2 .2)$ & 2 & - & - \\
\hline & Resonant in terms of culture or heritage (3.1.2.3) & 3 & 82 & 7 \\
\hline & Aesthetic experiences (3.1.2.4) & 11 & 172 & 119 \\
\hline $\begin{array}{c}\text { Other } \\
\text { benefits }\end{array}$ & Economic benefits (tourism, work generation) & - & 103 & 1 \\
\hline \multirow{6}{*}{$\begin{array}{c}\text { ก̃ } \\
\text { Iิ } \\
0 \\
.0 \\
0 \\
0 \\
0 \\
\text { I } \\
\end{array}$} & Work charge & 7 & - & - \\
\hline & Physical obstacle & 12 & - & 267 \\
\hline & Impact on agricultural production & 9 & - & - \\
\hline & Damages on equipment $\&$ infrastructures & 10 & 19 & - \\
\hline & Legislative constraints & 3 & - & - \\
\hline & Other economic costs & 4 & - & 1 \\
\hline \multirow{2}{*}{ 壱 } & Safety issues caused by dead biomass production & 3 & - & - \\
\hline & Dangerous animals & 2 & - & - \\
\hline \multirow{3}{*}{ 竺令 } & Damage on panoramic view & - & - & 121 \\
\hline & Isolation & - & - & 16 \\
\hline & Decrease in existence value & - & - & 127 \\
\hline
\end{tabular}

The ES classification is based on the CICES 5.1. The EDS classification is inspired by Shackleton et al. (2016) but adapted to this study.

\section{Contrasted ES/EDS perceptions according to forested areas in the Agroforestry study case}

In the Agroforestry case study, the 18 farmers (16 men and 2 women) were between 31 and 68 years old. Nine of them had a conventional mixed farming system (combining crop cultivation and animal raising), six of them had a conventional crop cultivation system, and three had an organic crop cultivation system. All farmers had forested areas on their farmland that were regrouped into nine different types on the basis of interviews. The number of occurrences of ES/EDS classes differed between the different types of forested areas (Table 2). Hedgerows and woods were perceived as the best sources of ES (74 and 73 occurrences, respectively). For example, hedgerows were appreciated for firewood and fruit production, for their role on erosion control and on wildlife conservation, and for their participation in the landscape scenic value. Woods were particularly cited as a source of timber, 
firewood and mushrooms, contributing to air quality and to a positive impact on ecosystems and landscape scenic value. Conversely, groves, tree alignments and heathlands showed the lowest occurrences of ES. In the meantime, farmers associated 8 EDS to forested areas, in particular with hedgerows, edge trees and isolated trees (Table 2). Most cited EDS were associated with the fact that those trees hinder farmers working with tractors and other mechanized tools, cause damages to these machines and on infrastructures (such as buildings and ditches) and thus represent extra labor due to management requirements to reduce these EDS. On the contrary, heathlands, groves and tree alignments were associated with less EDS, certainly because they have less spatial overlap with agricultural plots.
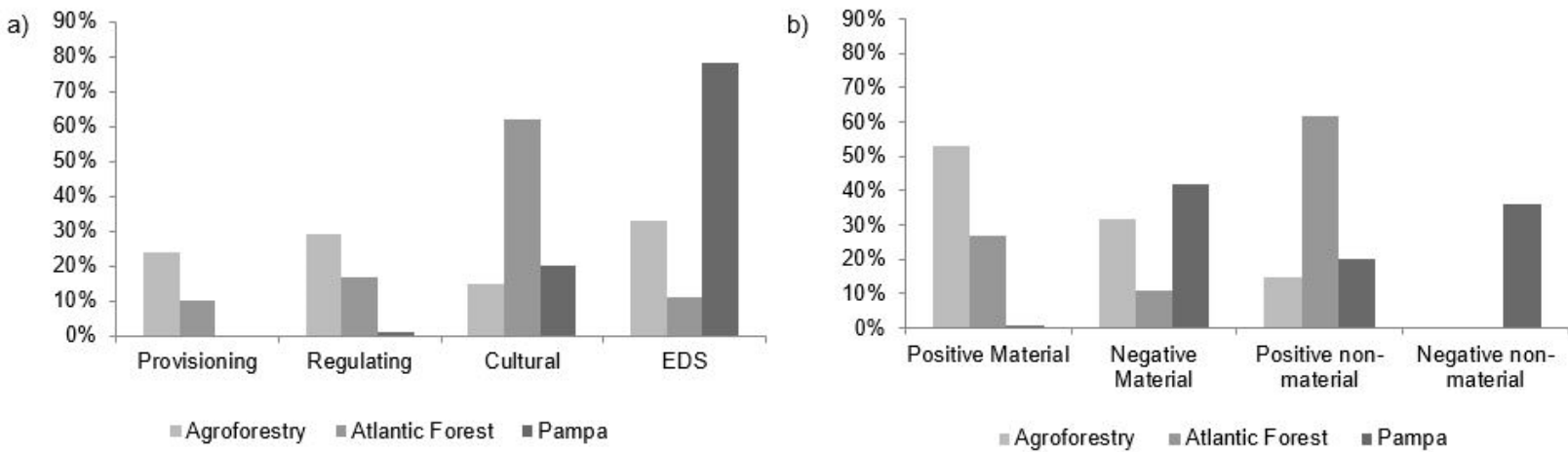

Fig 2 Proportion of interviewees' responses for each type of: a) ecosystem services, including provisioning, regulating, and cultural ES), and ecosystem disservices; and b) contributions: positive material, negative material, positive non-material, and negative non-material.

Finally, results showed that the different types of forested areas had a contrasting balance between perceived ES and EDS (Fig. 3). Some forested areas, especially hedgerows, had high scores for both ES and EDS, whereas other areas, especially tree alignments and groves, had low scores. In addition, edge trees and riverbank trees had similar scores for ES, but edge trees provided more EDS than riverbank trees (Fig. 3). Finally, woods and isolated trees had similar EDS score, but woods provided much more ES than isolated trees.

\section{Contrasted preferences between stakeholders in the Atlantic case study}

In the Atlantic Forest case study, the 175 interviewees were between 18 and 81 years old. More than $50 \%$ of the tourists were visiting the region for the first time, whilst the residents were long-term residents (between 10 to 30 years in the area). Only $20 \%$ of the residents were farmers in conventional farming, with farm sizes ranging from 10 to 24 ha. The other $80 \%$ of residents had direct economic incomes from tourism, as owners of lodging, food and transport facilities or as attendants in restaurants and souvenir stores. Despite these differences, $98 \%$ of residents and tourists perceived the landscape scenic value, i.e. a cultural ES, as the most important ES. In particular, Araucaria forest was the most appreciated forest type for this ES. Both residents and tourists also perceived the damages to infrastructures as the main EDS. For 63\% of residents, heritage was the second most cited ES, and was mainly associated with the Atlantic forest type, as symbol of place-based identity. A large majority of tourists (89\%) cited existence value and health or enjoyment benefits as two important cultural ES. According to the interviews, these ES reinforced their motivations to visit the area in search of enjoyment, stress relief and personal growth. Yet, tourists also perceived provisioning ES (63\% of them), in particular fiber. On the contrary, residents rather insisted on air quality regulation (69\%). Overall, pine forest was the less appreciated forest type among residents and tourists, mentioned by less than $10 \%$ of informants. 
Table 2 Number of occurrences of each ES/EDS class during interviews with farmers according to the types of forested areas in the Agroforestry case study.

\begin{tabular}{|c|c|c|c|c|c|c|c|c|c|c|}
\hline Type & ES and EDS classes & Hedgerows & Woods & $\begin{array}{c}\text { Isolated } \\
\text { trees }\end{array}$ & Heathlands & $\begin{array}{l}\text { Edge } \\
\text { trees }\end{array}$ & $\begin{array}{c}\text { Riverbank } \\
\text { trees }\end{array}$ & $\begin{array}{c}\text { Road } \\
\text { trees }\end{array}$ & Groves & $\begin{array}{c}\text { Tree } \\
\text { alignments }\end{array}$ \\
\hline $\begin{array}{c}\text { Provision } \\
\text { ES }\end{array}$ & $\begin{array}{l}\text { Wild plants used as a source of energy } \\
\text { Wild plants used for nutrition } \\
\text { Fiber and other materials from wild plants } \\
\text { Wild animals used for nutrition } \\
\text { Biomass for agricultural use } \\
\text { Total }\end{array}$ & $\begin{array}{l}6 \\
7 \\
- \\
1 \\
- \\
\mathbf{1 4}\end{array}$ & $\begin{array}{c}13 \\
12 \\
7 \\
1 \\
- \\
33\end{array}$ & $\begin{array}{l}2 \\
6 \\
- \\
- \\
- \\
8\end{array}$ & $\begin{array}{l}1 \\
2 \\
- \\
1 \\
1 \\
5\end{array}$ & $\begin{array}{l}5 \\
1 \\
2 \\
- \\
- \\
\mathbf{8}\end{array}$ & $\begin{array}{c}5 \\
1 \\
3 \\
1 \\
- \\
\mathbf{1 0}\end{array}$ & $\begin{array}{l}4 \\
2 \\
- \\
- \\
- \\
6\end{array}$ & $\begin{array}{l}2 \\
4 \\
- \\
1 \\
- \\
7\end{array}$ & $\begin{array}{l}2 \\
- \\
- \\
- \\
- \\
2\end{array}$ \\
\hline $\begin{array}{c}\text { Regulation } \\
\text { ES }\end{array}$ & $\begin{array}{l}\text { Filtration by plants } \\
\text { Visual screening } \\
\text { Control of erosion rate } \\
\text { Water flow regulation } \\
\text { Wind protection } \\
\text { Maintaining nursery populations \& habitats } \\
\text { Decomposition and fixing process \& their } \\
\text { effect on soil quality } \\
\text { Regulation of air temperature and humidity } \\
\text { Total }\end{array}$ & $\begin{array}{c}1 \\
1 \\
9 \\
1 \\
8 \\
10 \\
2 \\
7 \\
\mathbf{3 9}\end{array}$ & $\begin{array}{c}- \\
- \\
3 \\
1 \\
5 \\
4 \\
- \\
7 \\
\mathbf{2 0}\end{array}$ & $\begin{array}{l}- \\
- \\
- \\
- \\
- \\
2 \\
- \\
7 \\
9\end{array}$ & $\begin{array}{l}- \\
- \\
- \\
- \\
2 \\
2 \\
- \\
2 \\
6\end{array}$ & $\begin{array}{c}- \\
- \\
3 \\
1 \\
3 \\
3 \\
2 \\
5 \\
17\end{array}$ & $\begin{array}{c}- \\
- \\
3 \\
1 \\
1 \\
3 \\
- \\
5 \\
\mathbf{1 3}\end{array}$ & $\begin{array}{l}- \\
- \\
1 \\
- \\
- \\
1 \\
- \\
4 \\
6\end{array}$ & $\begin{array}{l}- \\
- \\
- \\
- \\
1 \\
1 \\
- \\
1 \\
\mathbf{3}\end{array}$ & $\begin{array}{l}- \\
- \\
2 \\
- \\
1 \\
2 \\
- \\
1 \\
6\end{array}$ \\
\hline $\begin{array}{c}\text { Cultural } \\
\text { ES }\end{array}$ & $\begin{array}{l}\text { Passive or observational interactions } \\
\text { Existence value } \\
\text { Option or bequest value } \\
\text { Resonant in terms of culture or heritage } \\
\text { Aesthetic experiences } \\
\text { Total }\end{array}$ & $\begin{array}{c}2 \\
6 \\
3 \\
1 \\
9 \\
\mathbf{2 1} \\
\end{array}$ & $\begin{array}{c}2 \\
7 \\
3 \\
1 \\
7 \\
\mathbf{2 0}\end{array}$ & $\begin{array}{c}- \\
3 \\
1 \\
2 \\
4 \\
\mathbf{1 0}\end{array}$ & $\begin{array}{c}1 \\
5 \\
2 \\
- \\
6 \\
\mathbf{1 4} \\
\end{array}$ & $\begin{array}{l}- \\
3 \\
1 \\
1 \\
4 \\
9\end{array}$ & $\begin{array}{l}- \\
2 \\
2 \\
- \\
4 \\
8\end{array}$ & $\begin{array}{l}- \\
3 \\
1 \\
- \\
4 \\
8 \\
\end{array}$ & $\begin{array}{l}1 \\
2 \\
3 \\
- \\
3 \\
9 \\
\end{array}$ & $\begin{array}{l}- \\
1 \\
- \\
- \\
2 \\
\mathbf{3} \\
\end{array}$ \\
\hline Total ES & & 74 & 73 & 27 & 25 & 34 & 31 & 20 & 19 & 11 \\
\hline $\begin{array}{c}\text { Economic } \\
\text { EDS }\end{array}$ & $\begin{array}{l}\text { Work charge } \\
\text { Physical obstacle } \\
\text { Impact on agricultural production } \\
\text { Damages on equipment \& infrastructures } \\
\text { Legislative constraints } \\
\text { Other economic costs }\end{array}$ & $\begin{array}{c}5 \\
10 \\
11 \\
6 \\
3 \\
3\end{array}$ & $\begin{array}{l}2 \\
2 \\
4 \\
5 \\
2 \\
1\end{array}$ & $\begin{array}{l}1 \\
6 \\
4 \\
2 \\
2 \\
1\end{array}$ & $\begin{array}{l}1 \\
- \\
4 \\
- \\
1 \\
2\end{array}$ & $\begin{array}{l}4 \\
4 \\
5 \\
5 \\
2 \\
1\end{array}$ & $\begin{array}{l}3 \\
4 \\
3 \\
3 \\
2 \\
-\end{array}$ & $\begin{array}{l}1 \\
2 \\
4 \\
2 \\
- \\
-\end{array}$ & $\begin{array}{l}1 \\
1 \\
2 \\
1 \\
1 \\
-\end{array}$ & $\begin{array}{l}2 \\
1 \\
1 \\
1 \\
- \\
-\end{array}$ \\
\hline $\begin{array}{c}\text { Health } \\
\text { EDS }\end{array}$ & $\begin{array}{l}\text { Safety issues caused by dead biomass } \\
\text { production } \\
\text { Dangerous animals }\end{array}$ & - & - & $\begin{array}{l}- \\
1\end{array}$ & - & $\begin{array}{l}1 \\
1\end{array}$ & - & $\begin{array}{l}1 \\
-\end{array}$ & - & - \\
\hline Total EDS & & 38 & 16 & 17 & 8 & 23 & 15 & 10 & 6 & 5 \\
\hline
\end{tabular}




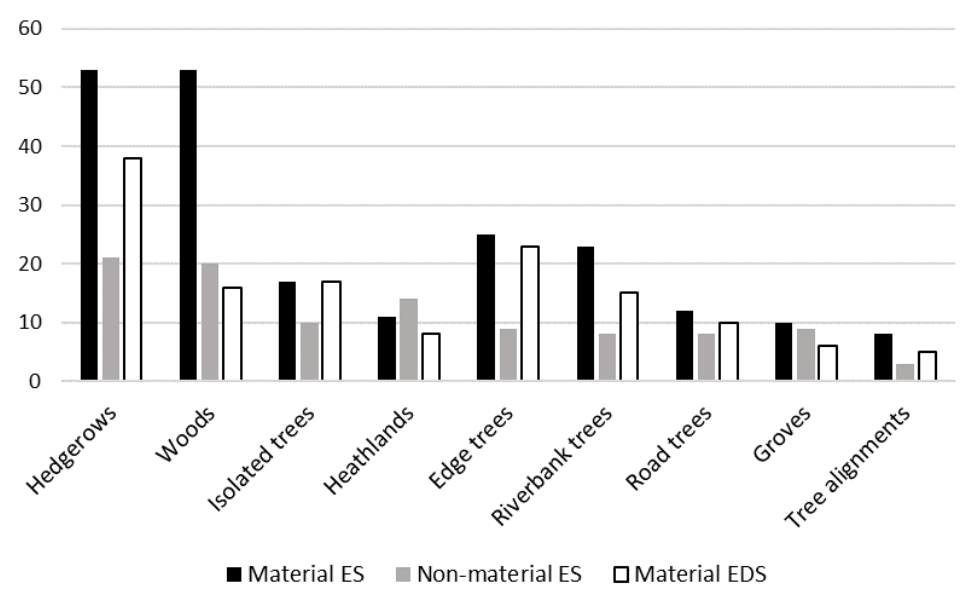

Fig 3 Number of occurrences for material and non-material ES/EDS as cited by farmers according to the type of forested areas in the Agroforestry case study. Note that no non-material EDS were cited in this case study.

The subgroups from the Atlantic Forest study case were plotted in a two-dimensional map using a Correspondence Analysis (CA) that explained $84.6 \%$ of the variability (Fig. 4). On the right side of the first dimension were youngest informants (from 18 to 30 years old) with high education level, named the "new generation". These subgroups particularly cited cultural ES such as heritage and observational value in association with Araucaria forest and eucalyptus plantation. They were also associated with economic benefits derived from touristic activities. The subgroups within the "new generation" quadrant contrasted with the ones within the "old faithful" quadrant, which was represented by elderly people (from 40 to 81 years old), who tended to rather value Atlantic forest and pine forest. The tourists' subgroups were present in two quandrants, i.e. "fun and rest enthusiast" and the "experience enthusiast" (Fig. 4, on the left side of the plot). The subgroups within the "fun and rest enthusiast" quadrant were characterized by graduated and post-graduated adults (from 30 to 40 years old). These subgroups are associated with cultural ES such as health or enjoyment, which also clusters with the Araucaria forest. The most cited EDS by these subgroups was infrastructure damage caused by the traffic of heavy trucks doing the transportation of eucalyptus in the roads used by local residents and tourists to access the district of Monte Verde, which can influence negatively the image of the destination. The subgroups within the "experience enthusiast" quadrant were characterized by young adults, adults and elders (from 20 to 70 years old) with high education. The short distance of these subgroups to existence value and aesthetics as major cultural ES reinforce the interest of tourists for scenic contemplation. Yet, they also cited fiber as a crucial provisioning ES, which appeared to be linked to the wood house raw material found in the tourist commerce center. Finally, all tourist subgroups cited heritage and observational values as two important cultural ES, which are closer in the graph and, therefore, can be related with Araucaria forests and eucalyptus plantations (Fig. 4).

\section{Resident perceptions of exotic plantations in the Pampa case study}

In the Pampa case study, most interviewees were over than 50 years old (average: $53 \pm 15$ SD) and almost half of them had not concluded elementary school. Most of the interviewees owned small rural properties $(46 \%$ of interviewees owned properties with less than $50 \mathrm{ha}$ ), while a small proportion was composed of workers from nearby properties (cattle raisers and farmers). From all interviewees, 823 respondents (57\%) mentioned that they noticed landscape alterations and $690(47.7 \%)$ associated these alterations to eucalyptus plantations. For those who mentioned landscape alterations, eucalyptus plantations were especially perceived as a physical obstacle (cited by 
$39 \%$ ), associated with a decrease in existence value (19\%) and of panoramic view (18\%). On the other hand, part of the residents that mentioned landscape alterations considered that eucalyptus plantation positively contributed to landscape scenic value (17\%), but very few informants cited existence value (2\%) and air quality regulation (1\%). Thus, eucalyptus plantations were also receiving a positive appreciation.

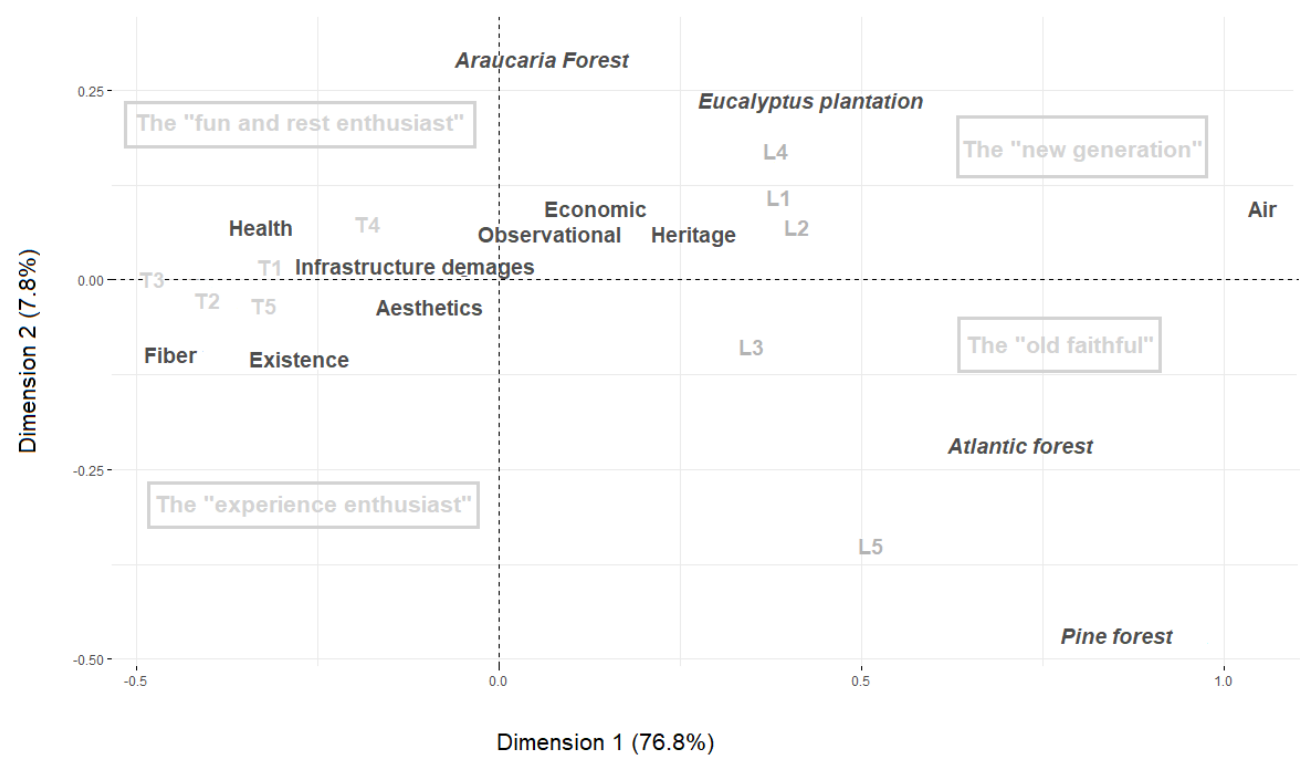

Fig 4 Correspondence analysis plot showing the position of the subgroups of stakeholders (in dark grey, "L" for local residents; in light grey, " $\mathrm{T}$ " for tourists), ES/EDS (in bold) and forest types (in italic) from the Atlantic Forest case study. The names given to the quadrants are within gray boxes.

A CA was used to plot subgroups of informants in a two-dimension map that explains $79.4 \%$ of the variability (Fig. 5). On the right side of the first axis, "Region I" shows the subgroups characterized by young adults and adults (from 18 to 30 years old) graduated from high school. These subgroups were associated with isolation as the main EDS, as well as with existence value as the main ES. The subgroups within "Region II" were represented by adults and elders (from 20 to 77 years old) graduated from high school. Part of the interviewees from this region has mentioned aesthetics as a cultural ES, while some have mentioned the decrease in existence value and in panoramic view as EDS. The proximity between these ES and EDS categories on the right side of the twodimensional map suggests that they were mentioned by people with similar profiles from "Region II". On the left side of the map (Fig. 5), the subgroups within "Region III" are composed by young adults (from 18 to 20 years old) with high school and adults and elders (from 40 to 90 years old) with incomplete elementary school. They emphasized the physical obstacles created by eucalyptus plantations, such as blockage of cell-phone signal and the loss of heritage value. Furthermore, these subgroups cited economic benefits associated with eucalyptus plantations (creation of jobs, regional economic activity), which indicates the positive outcomes expected from plantations on young residents' employment opportunities. Yet, they also acknowledged that plantations are visual obstacles decreasing the panoramic view valued by them. Finally, the CA map showed that EDS were frequently cited, i.e. they are located in the center of the map (Fig. 5), and that only a minority of informants recognized eucalyptus plantations as a source of ES. 


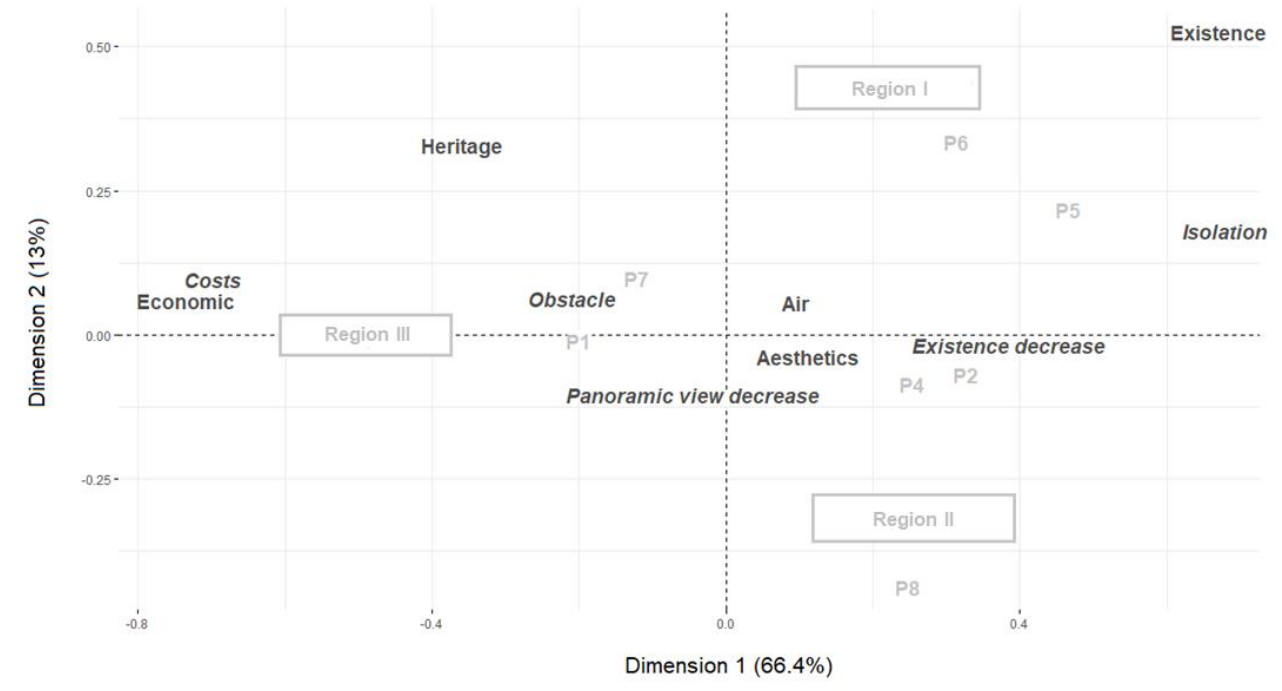

Fig 5 Correspondence analysis plot showing the position of the subgroups of stakeholders (in grey, "P" for subgroups), ES (in bold) and EDS (in italic) from the Pampa case study. The subgroups resulted from the Multiple Correspondence Analysis based on education level and age of the interviewees. All ES and EDS refer to one forest type, the exotic eucalyptus plantation. We divided the graph in regions (within gray boxes) to better discuss the answers of the subgroups.

\section{Discussion}

People's preferences and perceptions: lessons for local management

In combining three case studies in contrasted landscapes, this paper illustrated the interest of landscape preference studies to reveal local dynamics and provide site-specific recommendations for landscape management. In the Agroforestry case study, we found that farmers cited more ES than EDS, suggesting an overall positive attitude towards trees. This result echoes with other studies in Europe on farmers relationships with trees in wood-pastures in Sweden (Garrido et al. 2017), and on farmers attitudes towards agroforestry (García de Jalón et al. 2017). In regions where trees and forests are part of the history and identity of the place, they tend to be positively perceived by local stakeholders, including farmers. Yet, we also found that farmers perceive multiple EDS associated with forested areas, and value the different types of forested areas differently. In particular, some forested areas, such as hedgerows, were associated with high levels of both ES and EDS. Some other areas, such as woods, offered high levels of ES but low levels of EDS. Finally, other areas were linked with low amounts of both ES and EDS. Considering that in the Agroforestry case study region, hedgerows and isolated trees have declined over the last decades while woods have been relatively stable (Blanco et al. 2018), our results have two implications. First, the overall positive perception of farmers towards trees does not necessarily imply a positive attitude (i.e. a management in favor of the maintenance of trees), because farmers are also affected by EDS and by other economic, social and/or legal constraints (Tsonkova et al. 2018). Second, it seems that the more EDS perceived by farmers, the more farmers tend to remove forested areas, notwithstanding the level of ES. Indeed, while woods and hedgerows had similar values in terms of ES (Table 2), hedgerows were a more prominent source of EDS for farmers, which may partly explain their decline. Finally, our results in the Agroforestry case study have allowed to identify ES that are important to farmers. These ES could serve as incentives to incite farmers to replant hedgerows and other trees outside forests on their farmland. For example, as firewood is a well-known ES among farmers, helping them to better value this firewood may contribute to the promotion of trees on farmlands. 
Meanwhile, our study also allowed to identify the main EDS that prevent farmers from maintaining trees on their farms. Decision makers should better account for these EDS to design ad-hoc policies.

In the Atlantic Forest case study, we also found a positive vision of people regarding forested areas. Because of the touristic value of this landscape, people, and especially tourists, rather valued the non-material dimensions of forests. Yet, local residents and entrepreneurs also had high preferences for cultural ES, in addition to economic outcomes, and associated native forests with their identity and sense of belonging. This result evidences the consolidation of the cultural values of the Atlantic forest such as aesthetics (Krieger 2001), that in turn is associated to economic benefits from the forest related to tourism. Unfortunately, the ES framework from CICES has a limited classification to represent the advantages of ecosystems as cultural ES, that's why the economic benefit perceived by the local residents has to be in a separate type called "other benefits". Finally, this testifies that forests produce several ecosystem services that enable tourism development, create jobs and generate income for local people, characterizing a kind of value chain. Furthermore, stakeholders in this case study easily associated ES/EDS with specific types of forests (i.e. dense Atlantic forest, Araucaria forest), as well as their respective potential for tourism. Finally, we did not find any disjuncture between aesthetics and ecology in this case, as raised by Gobster et al. (2007). Indeed, all forest types were associated with both regulating and cultural ES, suggesting a convergence between societal demands and the maintenance of important ES.

In the Pampa case study, we highlighted the importance of EDS to local residents associated with eucalyptus plantations. Furthermore, our results illustrate the low social acceptancy of planted forests and exotic species by people in this region, where native grasslands historically occupied the landscape. Former studies have shown that the perceptions of forests by local people depend on the local forest history: in areas where forests were historically absent, people tend to poorly value forests (Elands et al. 2004; Ní Dhubháin et al. 2009). Henderson et al. (2016) also identified that forest plantations are significantly less desirable than other landscape types by landowners in the Pampa region. This preference is related to the subjective dimensions of the landscape recognized by local residents in a region where the landscape was historically composed mostly by grasslands, resulting in a cultural dimension related to people's cultural identity. An attempt to counteract the EDS associated with planted exotic forests and to consider the subjective meanings of the landscape in land management could be to regulate their expansion through establishing limits in stand size and environmental zonation per municipality. This is currently being done at the state level in Pampa grasslands in southern Brazil through the Environmental Zoning for Silvicultural Activity (Gautreau and Vélez 2011; FEPAM 2010), although not free of political pressure.

Capturing people's perceptions of ecosystem services and disservices by bridging ES and the landscape approaches: lessons for research

By bridging across "the landscape" and ES approaches this paper was able to identify commonalities between the three case studies, which could have several implications for future studies on landscape preferences and people's perceptions. Firstly, we showed that stakeholders have different preferences in relation to forests because of contrasted individual and collective visions and objectives, but also because of site-specific differences. On the one hand, our results suggest that local stakeholders, such as farmers and local residents, tend to have a more complex and holistic vision of forests, whereas external stakeholders, such as tourists, tend to perceive only a few aspects of forests' contributions. For example, the Agroforestry case study illustrates how forests could be important for local people (Sourdril et al. 2012), but at the same time, a source of problems and issues. On the 
other hand, we saw that local perceptions of forests vary among case studies according to the history and livelihoods (Da Ponte et al. 2017). Thus, while sociocultural valuation of ES allowed gaining a better understanding of how people value ES, exploring the underlying factors of this valuation represents a challenge for future research.

Secondly, in our three case studies, people were concerned with different types of EDS associated with forests. The concept of EDS has been applied in urban forest studies (e.g. Lyytimäki et al. 2008; Conway and Yip 2016) to help balance between the positive and negative contributions of green areas in cities. However, less research has investigated EDS associated with forests in rural landscapes (but see Ango et al. 2014; Hansen 2014). As our results suggest, this lower interest in EDS than in ES from researchers is detrimental to (i) the ES assessments undertaken in the purpose of helping decision makers and (ii) our understanding of the links between human and ecological systems. As suggested by Schaubroeck (2017), studying both ES and EDS would enable a more balanced assessment of nature's contributions to human well-being. As illustrated by our case studies, people consider that the same ecosystem attribute can simultaneously be a source of services and disservices. Furthermore, as shown by the Agroforestry and Pampa case study, enhancing the ES supply could also enhance the EDS supply. In planting eucalyptus, provisioning ES such as fiber may effectively increase, while discomforts are locally generated (issues with cell-phone signal, decrease in scenic value). Thus, if decision makers are only advised on the basis of ES assessments and through recommendations focused on ES maximization only, EDS could also increase unexpectedly and induce negative feedbacks. Assessing ES/EDS bundles represents a promising way to counteract this issue (Campagne et al. 2018). Another important contribution of this work is to highlight that EDS are part of both people's preferences and perceptions. Thus, if we aim at better understanding people's views and behavior regarding ecosystems, EDS should be more systematically introduced in sociocultural valuation surveys. This integration may help to better analyze the link between people's perceptions, their actions, and their influence on ecosystems. For example, the Agroforestry case study illustrated the potential influence of how people perceive EDS on their action on the landscape; despite their association with several ES, hedgerows declined because they were a source of EDS in the new agricultural settings. Woods that provided also ES were not an important source of EDS, which may partly explain their maintenance (Blanco et al. 2018). The combination of ES and EDS therefore appear as a promising enterprise for enlarging our understanding of the socioecological processes that occur in anthropogenic landscapes worldwide. For this assessment to be comprehensive, the bridge across the diversity of methods of "the landscape approach" (Simensen et al. 2018) and of ES approaches are of utmost value.

\section{Limits and perspectives of this research}

Assessing the sociocultural value of ecosystem services and disservices is not an obvious enterprise and several methods have been used in the literature (Scholte et al. 2015). Firstly, because of the different methods presented in this paper, comparisons among case studies were not relevant, even if we have been able to draw common lessons. There is no perfect method and it is important to be aware of their limitations and strengths according to the research purpose (Simensen, Halvorsen et al. 2018). In-depth interviews (the method used in the Agroforestry case study) are a recognized method to investigate people's relationships with nature and to enter in their multidimensionality and complexity (Oreszczyn 2000). They are especially important in landscape research to analyze how stakeholders deal with a complex world. Our results therefore showed that this method was able to capture a greater diversity of ES and EDS. However, in-depth interviews require long investigation periods and 
long transcription and analysis phases at the expense of the number of interviewees, which prevents conducting large-scale analyses and limits statistical treatment. In contrast, questionnaires (used in the Atlantic Forest and Pampa case studies) allowed working with large samples and the identification of global trends. As they provide easy to catch quantitative data, questionnaires may also have a greater impact on decision makers. Yet, although they allow testing a given hypothesis, questionnaires fail to deal with "outside of the box" phenomena and to tackle complex situations. Therefore, when working with questionnaires (including photo-questionnaires) we are more likely to be assessing landscape preferences rather than capturing more complex perceptions. In order to have the best of the two worlds, it is therefore common in the literature to combine a preliminary research phase based on in-depth interviews with key informants, and a second phase based on questionnaires submitted to a larger sample of people (e.g. Limburg et al. 2010). This could be a perspective of research for the French case study. Secondly, one main limitation of this study comes from the lack of consisting EDS classification. Over the last decades, research on ES had advanced significantly, including internationally accepted classifications of ES - such as the European classification (CICES) that we used in this study (Haines-Young and Potschin 2018) and the US classification (FEGS-ES, Landers and Nahlik 2013). For this research, we had no problem in using this classification, designed thanks to a large amount of research and expertise in contrasted socioecological systems and contexts, to design our surveys and to analyze interviews. On the contrary, as no such internationally accepted classification of EDS exists, it was more challenging to find a satisfactory way to classify EDS, in particular given the specificity of each case study. We think that research on EDS should be reinforced in order to design a relevant classification that could be of great help to researchers and managers.

\section{Conclusions}

This study explored stakeholders' perceptions of the ES and EDS associated with trees in three case studies with contrasted management challenges. While research has been mainly focusing on the positive contributions of forests to human wellbeing (i.e. forest-related ES), our results emphasized the simultaneous existence of negative contributions (i.e. forest-related EDS). Firstly, we showed that forests are perceived as a source of either ES, either EDS, but that most people acknowledge both ES and EDS simultaneously. Secondly, we highlighted that, just as ES, EDS are differently perceived by people, according to individual objectives, backgrounds and sociocultural attributes. Thirdly, we emphasized that ES and EDS perceptions differ according to forest types, but also according to forest management, which highlights that ES and EDS are co-produced by ecosystem function and attributes and human management choices. Finally, in combining ES and EDS concepts to address landscape preference and perceptions, this study allowed to advance in the understanding of people's attitudes towards different types of forests and landscapes. On the basis of local perceptions and preferences of landscape users and managers, we were able to formulate recommendations for landscape planning and management in the three case studies. Yet, because EDS is an emerging and debated concept, critical conceptual and methodological issues remain to be addressed before it could become an operational concept, including the development of an internationally accepted classification and definition. As our results suggest, a promising research perspective would be to integrate ES and EDS in a consistent framework in order to better analyze the complexity of human-nature material and nonmaterial interactions, and to facilitate the dialogue among stakeholders, researchers and policy makers. 


\section{Acknowledgements}

From the Agroforestry case study, we would like to thank the grants from the 'Fondation de France' that supported this work. We are grateful to the farmers and inhabitants of the Canton of Aurignac, to the tourists, entrepreneurs and local residents of Monte Verde district, and to the local inhabitants of the Pampa biome who participated in these interviews for their willingness to participate in our research. We also appreciate the collaborators of the Atlantic Forest and the Pampa case studies for data collection. FZT received a postdoctoral fellowship from the 'Coordenação de Aperfeiçoamento de Pessoal de Ensino Superior' (PNPD/CAPES).

\section{References}

Agbenyega O, Burgess PJ, Cook M, Morris J (2009) Application of an ecosystem function framework to perceptions of community woodlands. Land Use Policy 26:551-557

Agrawal A, Ostrom E (2006) Political science and conservation biology: a dialog of the deaf. Conserv Biol 20:681-682

Almeida M, Loupa-Ramos I, Menezes H, Carvalho-Ribeiro S, Guiomar N, Pinto-Correia T (2016) Urban population looking for rural landscapes: different appreciation patterns identified in Southern Europe. Land Use Policy 53:44-55. https://doi.org/10.1016/J.LANDUSEPOL.2015.09.025

Ango TG, Börjeson L, Senbeta F (2016) Crop raiding by wild mammals in Ethiopia: impacts on the livelihoods of smallholders in an agriculture-forest mosaic landscape. Oryx 51:1-11

Ango TG, Börjeson L, Senbeta F, Hylander K (2014) Balancing ecosystem services and disservices: smallholder farmers' use and management of forest and trees in an agricultural landscape in southwestern Ethiopia. Ecol Soc. https://doi.org/10.5751/es-06279-190130

Antrop M(2000) Background concepts for integrated landscape analysis. Agric Ecosyst Environ 77:17-28. https://doi.org/10.1016/S0167-8809(99)00089-4

Arts B, Buizer M, Horlings L, Ingram V, Van Oosten C, Opdam, P (2017) Landscape approaches: a state-of-theart review. Annu Rev Environ Resour 42:439

Baró F, Haase D, Gómez-Baggethun E, Frantzeskaki N (2015) Mismatches between ecosystem services supply and demand in urban areas: a quantitative assessment in five European cities. Ecol Indic 55:146-158

Agbenyega O, Burgess PJ, Cook M, Morris J (2009) Application of an ecosystem function framework to perceptions of community woodlands. Land Use Policy 26:551-557

Agrawal A, Ostrom E (2006) Political science and conservation biology: a dialog of the deaf. Conserv Biol 20:681-682

Almeida M, Loupa-Ramos I, Menezes H, Carvalho-Ribeiro S, Guiomar N, Pinto-Correia T (2016) Urban population looking for rural landscapes: different appreciation patterns identified in Southern Europe. Land Use Policy 53:44-55. https://doi.org/10.1016/J.LANDUSEPOL.2015.09.025

Ango TG, Börjeson L, Senbeta F (2016) Crop raiding by wild mammals in Ethiopia: impacts on the livelihoods of smallholders in an agriculture-forest mosaic landscape. Oryx 51:1-11

Ango TG, Börjeson L, Senbeta F, Hylander K (2014) Balancing ecosystem services and disservices: smallholder farmers' use and management of forest and trees in an agricultural landscape in southwestern Ethiopia. Ecol Soc. https://doi.org/10.5751/es-06279-190130

Antrop M(2000) Background concepts for integrated landscape analysis. Agric Ecosyst Environ 77:17-28. https://doi.org/10.1016/S0167-8809(99)00089-4

Arts B, Buizer M, Horlings L, Ingram V, Van Oosten C, Opdam, P (2017) Landscape approaches: a state-of-theart review. Annu Rev Environ Resour 42:439

Baró F, Haase D, Gómez-Baggethun E, Frantzeskaki N (2015) Mismatches between ecosystem services supply and demand in urban areas: a quantitative assessment in five European cities. Ecol Indic 55:146-158

Garrido P, Elbakidze M, Angelstam P (2017) Stakeholders' perceptions on ecosystem services in O* stergo“tland's (Sweden) threatened oak wood-pasture landscapes. Landsc Urban Plan 158:96-104 
Gautreau P, Vélez E (2011) Strategies of environmental knowledge production facing land use changes: insights from the Silvicultural Zoning Plan conflict in the Brazilian state of Rio Grande do Sul. Cybergeo Eur J Geogr. https://doi.org/10.4000/cybergeo.24881

Gobster PH, Nassauer JI, Daniel TC, Fry G (2007) The shared landscape: what does aesthetics have to do with ecology? Landscape Ecol 22:959-972

Green RE, Cornell SJ, Scharlemann JPW, Balmford A (2005) Farming and the fate of wild nature. Science 307:550-555

Haines-Young R, Potschin MB (2018) Common International Classification of Ecosystem Services (CICES) V5.1 and Guidance on the Application of the Revised Structure. 27

Hansen WD (2014) Generalizable principles for ecosystem stewardship-based management of social-ecological systems: lessons learned from Alaska. Ecol Soc 19:art13

Henderson KA, Reis M, Blanco CC, Pillar VD, Printes RC, Bauch CT, Anand M (2016) Landowner perceptions of the value of natural forest and natural grassland in a mosaic ecosystem in southern Brazil. Sustain Sci 11:321330

Iniesta-Arandia I, García-Llorente M, Aguilera PA, Montes C, Martín-López B (2014) Socio-cultural valuation of ecosystem services: uncovering the links between values, drivers of change, and human well-being. Ecol Econ $108: 36-48$

Krieger D (2001) Economic value of forest ecosystem services: a review. The Wilderness Society, Washington, $\mathrm{DC}$

Lambin EF, Meyfroidt P, Rueda X, Blackman A, Börner J, Cerutti P, Dietsch T, Jungmann L, Lamarque P, Lister J,

Walker NF, Wunder S (2014) Effectiveness and synergies of policy instruments for land use governance in tropical regions. Glob Environ Chang 28:129-140

Landers DH, Nahlik AM (2013) Final ecosystem goods and services classification system (FEGS-CS). Report Number: EPA/600/R-13/ORD-004914

Lapola DM, Martinelli LA, Peres CA, Ometto JPHB, Ferreira ME, Nobre CA, Aguiar APD, Bustamante MMC, Cardoso

MF, Costa MH, Joly CA, Leite CC, Moutinho P, Sampaio G, Strassburg BBN, Vieira ICG (2014) Pervasive transition of the Brazilian land-use system. Nat Clim Chang 4:27-35

Limburg KE, Luzadis VA, Ramsey M, Schulz, KL, Mayer CM (2010) The good, the bad, and the algae: perceiving ecosystem services and disservices generated by zebra and quagga mussels. J Great Lakes Res 36:8692

Lyytimäki J (2014) Bad nature: newspaper representations of ecosystem disservices. Urban For Urban Green $13: 418-424$

Lyytimäki J, Petersen LK, Normander B, Bezák P (2008) Nature as a nuisance? Ecosystem services and disservices to urban lifestyle. Environ Sci 5:161-172

Martín-López B, Iniesta-Arandia I, García-Llorente M, Palomo I, Casado-Arzuaga I, Del Amo DG, GómezBaggethun E,

Oteros-Rozas E, Palacios-Agundez I, Willaarts B, González JA, Santos-Martín F, Onaindia M, López-Santiago C, Montes C (2012) Uncovering ecosystem service bundles through social preferences. PLoS ONE. https://doi.org/10.1371/journal.pone.0038970

Nenadic O, Greenacre M (2007) Correspondence analysis in R, with two- and three-dimensional graphics: the ca package. J Stat Softw 20:1-13

Ní Dhubháin Á, Fléchard M-C, Moloney R, O’Connor D (2009) Stakeholders' perceptions of forestry in rural areas - two case studies in Ireland. Land Use Policy 26:695-703

Ninan KN, Kontoleon A (2016) Valuing forest ecosystem services and disservices - case study of a protected area in India. Ecosyst Serv 20:1-14 Olson DM, Dinerstein E (2002) The global 200: priority ecoregions for global conservation. Ann Missouri Bot Gard 89:199 
Oreszczyn S (2000) A systems approach to the research of people's relationships with English hedgerows. Landsc Urban Plan 50:107-117

Ovaskainen V, Kniivila M (2005) Consumer versus citizen preferences in contingent valuation: evidence on the role of question framing*. Aust J Agric Resour Econ 49:379-394

Overbeck GE, Müller SC, Fidelis A, Pfadenhauer J, Pillar VD, Blanco CC, Boldrini II, Both R, Forneck ED (2007) Brazil's neglected biome: the South Brazilian Campos. Perspect Plant Ecol Evol Syst 9:101-116

Ramos IL, Bernardo F, Ribeiro SC, Van Eetvelde V (2016) Landscape identity: implications for policy making. Land Use Policy 53:36-43

Schaubroeck T (2017) A need for equal consideration of ecosystem disservices and services when valuing nature; countering arguments against disservices. Ecosyst Serv 26:95-97

Schirpke U, Timmermann F, Tappeiner U, Tasser E (2016) Cultural ecosystem services of mountain regions: modelling the aesthetic value. Ecol Indic 69:78-90

Scholte SSK, van Teeffelen AJA, Verburg PH (2015) Integrating socio-cultural perspectives into ecosystem service valuation: a review of concepts and methods. Ecol Econ 114:67-78

Sell J, Koellner T, Weber O, Proctor W, Pedroni L, Scholz RW (2007) Ecosystem services from tropical forestry projects - the choice of international market actors. For Policy Econ 9:496-515

Shackleton CM, Ruwanza S, Sinasson Sanni GK, Bennett S, De Lacy P, Modipa R, Mtati N, Sachikonye M, Thondhlana G (2016) Unpacking Pandora's box: understanding and categorizing ecosystem disservices for environmental management and human wellbeing. Ecosystems 19:587-600

Sheppard SRJ, Meitner M (2005) Using multi-criteria analysis and visualisation for sustainable forest management planning with stakeholder groups. For Ecol Manage 207:171-187

Simensen T, Halvorsen R, Erikstad L (2018) Methods for landscape characterisation and mapping: a systematic review. Land Use Policy 75:557-569

Sourdril A, Andrieu E, Cabanettes A, Elyakime B, Ladet S (2012) How to maintain domesticity of usages in small rural forests? Lessons from forest management continuity through a french case study. Ecol Soc 17:art6

Team RC (2017) R: A Language and Environment for Statistical Computing

Torralba M, Fagerholm N, Burgess PJ, Moreno G, Plieninger T (2016) Do European agroforestry systems enhance biodiversity and ecosystem services? A meta-analysis. Agric Ecosyst Environ 230:150-161

Tsonkova P, Mirck J, Böhm C, Fütz B (2018) Addressing farmer-perceptions and legal constraints to promote agroforestry in Germany. Agrofor Syst. https://doi.org/10.1007/s10457-018-0228-4

van der Zanden EH, Carvalho-Ribeiro SM, Verburg PH (2018) Abandonment landscapes: user attitudes, alternative futures and land management in Castro Laboreiro, Portugal. Reg Environ Chang. https://doi.org/10.1007/s10113-018-1294-X

Willemen L, Hein L, Verburg PH (2010) Evaluating the impact of regional development policies on future landscape services. Ecol Econ 69(11):2244-2254

Willemen L, Veldkamp A, Verburg PH, Hein L, Leemans R (2012) A multi-scale modelling approach for analyzing landscape service dynamics. J Environ Manag 100:86-95

Wolff S, Schulp CJE, Verburg PH (2015) Mapping ecosystem services demand: a review of current research and future perspectives. Ecol Indic 55:159-171

Wood SLR, Jones SK, Johnson JA, Brauman KA, Chaplin-Kramer R, Fremier A, Girvetz E, Gordon LJ, Kappel CV, Mandle L, Mulligan M, O'Farrell P, Smith WK, Willemen L, Zhang W, DeClerck FA (2018) Distilling the role of ecosystem services in the sustainable development goals. Ecosyst Serv 29:70-82 